\title{
PHYTOCHEMICAL COMPOSITION \\ OF THE HERBAL MIXTURES, WHICH CAUSES THEIR EFFECTIVENESS IN DIABETES MELLITUS
}

\author{
Savych A. O., Marchyshyn S. M.
}

\section{INTRODUCTION}

Diabetes mellitus is one of World Health Organization's priority issues, which requires immediate resolution as the epidemiological situation is gaining alarming proportions because the number of diabetic patients is increasing every year, and with it the number of deaths and disabilities due to the development of micro- and macro-angiopathies ${ }^{1}$. According to the official report from the International Diabetes Federation (2019), it is projected the increase of incidence of diabetes by 1.5 times by 2030 in the world, which will amount to more than 500 thousand patients ${ }^{2}$. An important problem of pharmacovigilance is that existing pharmacotherapy is able to reduce hyperglycemia, but it is not always able to stabilize fluctuations of glycemia values during the day and keep it at optimal level. This leads to the formation of a cascade of pathological processes - excessive glycation and inactivation of the body's antioxidant defense system, triggering free radical oxidation of lipids and, as a consequently, the development of oxidative stress, which leads to the development and progression of diabetic complications ${ }^{3}$.

In turn, oxidative stress, which is the result of the accumulation of reactive oxygen species (ROS: hydroperoxyl, superoxide, hydrogen peroxide and hydroxyl radicals), nitrogen molecules (RNS: peroxynitrite of active nitrogen) and some derivatives of heavy metals (iron and copper) is the main event for the development of insulin resistance. This may reduce peripheral insulin sensitivity through major molecular mechanisms such as $\beta$-cell dysfunction, inflammatory responses, decreased regulation

1 Sakamoto M. Type 2 diabetes and glycemic variability: various parameters in clinical practice, Journal of Clinical Medicine Research. 2018. Vol. 10(10). P. 737-742. DOI: $10.14740 /$ jocmr3556w.

${ }^{2}$ International Diabetes Federation. IDF Diabetes Atlas., 9th edn. Brussels, Belgium, 2019. URL: http://www.diabetesatlas.org.

3 American Diabetes Association, Standards of medical care in diabetes. Diabetes care. 2020. Vol. 43.1212 p. 
and/or localization of glucose transporter 4 (GLUT-4), mitochondrial dysfunction, and abnormal insulin signaling pathways ${ }^{4}$. Therefore, the implementation of pharmacotherapy optimization, the search and study of new drugs for the prevention and treatment of this disease and its complications is a top issue of pharmacy and medicine.

One of these areas is using the herbal remedies, as monotherapy in the mild stages of morbidity and for its prevention, as well as in combination with traditional therapy in more severe forms of disease. Phytotherapy is the justified method of prevention and treatment because it has some advantages, such as relatively low-toxicity, mild pharmacological effects and possibility to be used for long periods of time without significant sideeffects, and it often well combined with synthetic drugs 5 . Particular attention deserve the combinations of different medicinal plants, because such herbal mixtures are expected to have more biologically active substances with wide range of pharmacological action and a variety of mechanisms for influencing the development of diabetes (pathogenesis of which involves the development of insulin resistance, relative insulin deficiency, which leads to the decrease of secretory activity of $\beta$-cells of the pancreatic gland) and diabetic angiopathies (inactivation of antioxidant protection system, activation of lipid peroxidation and development of oxidative stress $)^{5,6}$.

Thus, the aim of the research was to study the relationship between previously identified phytocomponents of the investigated herbal mixtures and their pharmacodynamics and effectiveness in the treatment and prevention of diabetes mellitus type 2 and its complications.

\section{The herbal mixtures, their composition and pharmacological activities}

The pharmaceutical market of Ukraine is represented mainly by synthetic antidiabetic drugs, although the use of the medical herbs, especially their mixtures, has centuries of experience in folk medicine.

${ }^{4}$ Differentiation of diabetes by pathophysiology, natural history, and prognosis / J.S. Skyler, G.L. Bakris, E. Bonifacio [et al.] // Diabetes. 2017. Vol. 66(2). P. 241-255. DOI: $10.2337 / \mathrm{db} 16-0806$.

5 Phytotherapy in the management of diabetes: a review / P. Governa, G. Baini, V. Borgonetti [et al.] // Molecules.2018. Vol. 23 P. 105. DOI: 10.3390/molecules23010105.

${ }^{6}$ Основні принципи використання лікарських рослин та їх зборів для лікування та профілактики цукрового діабету 2 типу (Огляд літератури). Фітотерапія часопис / А.О. Савич та ін. 2019. № 4. С. 43-46. DOI: 10.33617/2522-9680-2019-4-43 
This is evidenced by the analysis of literature sources ${ }^{7}$. Therefore, the study of phytochemical composition and pharmacological properties of the herbal mixtures, the establishment of a link between their biologically active substances and the pathogenetic mechanism of action in diabetes mellitus, is a promising area in pharmacy and medicine.

For the study were used the twenty different herbal mixtures, which are used in folk medicine for the prevention and treatment of diabetes mellitus type 2 in Ukraine. The effectiveness of these phytomixtures was investigated in screening studies on normoglycemic rats using glucose loading tests ${ }^{8,9,10}$. Based on the results of this study, five mixtures that showed the best hypoglycemic activity were selected and their conditionally effective dose was established for further studies of their phytochemical composition and pharmacodynamics.

The herbal raw materials harvested in June to August 2019 in Ternopil region (Ukraine) were used. After harvesting, the raw materials were dried, crushed and brought back to standard according to the general GACP requirements ${ }^{11}$. The plants were identified by Department of Pharmacognosy with Medical Botany, I.Horbachevsky Ternopil National Medical University, Ternopil, Ukraine. The voucher specimens of the herbal raw materials have been deposited in Departmental Herbarium for future record.

Composition of the five herbal mixtures is given in Table 1.

After that, in the second phase of pharmacological studies on dexamethasone-indused insulin resistance rats, a number of pharmacodynamic properties of the selected herbal mixtures were revealed. The expressed antihyperglycemic properties, which were shown by decrease in blood glucose level during Oral Glucose Tolerance Test (OGTT) and

7 Товстуха Є.С. Золоті рецепти української народної медицини. Київ: Країна Мрій. 2010. 550 c.

${ }^{8}$ Savych A., Marchyshyn S., Basaraba R. Screening study of hypoglycemic activity of the herbal mixtures (Message 1). Scientific Journal «ScienceRise: Pharmaceutical Science». 2020. Vol. 4(26). P. 40-46. DOI: 10.15587/2519-4852.2020.210734.

${ }^{9}$ Savych A., Marchyshyn S., Doroshenko O. Screening of hypoglycemic activity of herbal mixtures (Message 2). Ukrainian biopharmaceutical journal. 2020. Vol. 3(64). P. 22-29. DOI: 10.24959/ubphj.20.281.

${ }^{10}$ Savych A. O., Marchyshyn S. M., Milian I. I. Screening study of hypoglycemic activity of herbal mixtures (Presentation 3). Clinical Pharmacy. 2020. Vol. 24(4). P. 38-46. DOI: $10.24959 / \mathrm{cphj} .20 .1537$.

11 World Health Organization.WHO Guidelines on Good Agricultural and Mixture Practices (GACP) for Medicinal Plants. Geneva, 2003, pp. 72. URL: https://apps.who.int/ iris/handle/10665/42783. 
Intraperitoneal Glucose Tolerance Test (IPGTT). In addition, the ability of the studied mixtures to regulate the lipid profile by reducing the content of total cholesterol, triglycerides and low-density lipoproteins and by increasing the content of high-density lipoproteins was revealed. An antioxidant properties were studied and were performed the ability of the five herbal mixtures to reduce malonic dialdehyde (MDA) in the blood and liver, to reduce the content of glutathione (GSH) in the blood and to increase its content in the liver, as well as to reduce the activity of superoxide dismutase (SOD) in the blood and liver and to reduce the activity of catalase (CAT) in the blood with a simultaneous increase in its activity in the liver ${ }^{12}$. The results from this study showed that the herbal mixtures exhibit the ability to regulate protein metabolism, possess potential hepatoprotective effect and reduce the disorders of functional activity of the liver on the background of insulin resistance in rats ${ }^{13,14}$.

Obviously, the effectiveness of the studied herbal mixtures is due to the presence of various biologically active substances.

Table 1

Composition of the herbal mixtures

\begin{tabular}{|c|l|c|c|}
\hline $\begin{array}{c}\text { Herbal } \\
\text { mixtures }\end{array}$ & \multicolumn{1}{|c|}{ Herbal drug component } & $\begin{array}{c}\text { Portion in the } \\
\text { mixture,\% }\end{array}$ & $\begin{array}{c}\text { Relative } \\
\text { ratio }\end{array}$ \\
\hline \multirow{5}{*}{ No. 3 } & Urtica dioica leaf & 26.32 & 5 \\
& Cichorium intybus roots & 26.32 & 5 \\
& Rosa majalis fruits & 21.05 & 4 \\
& Elymus repens rhizome & 15.79 & 3 \\
& Taraxacum officinale roots & 10.52 & 2 \\
\hline
\end{tabular}

${ }^{12}$ Savych A., Marchyshyn M., Basaraba R., Lukanyuk M. Antihyperglycemic, hypolipidemic and antioxidant properties of the herbal mixtures in dexamethasoneinduced insulin resistant rats. Pharmacologyonline. 2020. Vol. 2. P. 73-82.

${ }^{13}$ Savych A. O., Marchyshyn S. M. Influence of the herbal mixtures on the functional state of the liver in dexamethasone-induced insulin resistant rats. New trends and unresolved issues of preventive and clinical medicine: materials of the international scientific and practical conference. (Lublin, Republic of Poland, 23-24 of September, 2020). Lublin, 2020. P. 113-116. DOI: 10.30525/978-9934-588-81-5-2.27.

${ }^{14}$ Savych A., Marchyshyn M. Effect of the herbal mixture on protein metabolism in dexamethasone-induced insulin resistant rats. International E-conference contemporary pharmacy: issues, challenges and expectations: materials of the conference. (Kaunas, Lithuania, 23 of October, 2020). Kaunas, 2020. P. 59. 
Table 1 (continuance)

\begin{tabular}{|c|l|c|c|}
\hline \multirow{5}{*}{ No. 4} & Arctium lappa roots & 26.32 & 5 \\
& Elymus repens rhizome & 21.05 & 5 \\
& Zea mays columns with stigmas & 15.79 & 3 \\
& Helichrysum arenarium flowers & 10.52 & 2 \\
\hline \multirow{5}{*}{ No. 7} & Rosa majalis fruits & 10.0 & 1 \\
& Inula helenium rhizome with roots & 20.0 & 2 \\
& Helichrysi arenarium flowers & 20.0 & 2 \\
& Zea mays columns with stigmas & 20.0 & 2 \\
& Origanum vulgari herb & 20.0 & 2 \\
& Rosa majalis fruits & 10.0 & 1 \\
\hline \multirow{5}{*}{ No. 13} & Taraxacum officinale roots & 26.32 & 5 \\
& Cichorium intybus roots & 26.32 & 5 \\
& Elymus repens rhizome & 21.05 & 4 \\
& Helichrysum arenarium flowers & 15.79 & 3 \\
& Rosa majalis fruits & 10.52 & 2 \\
\hline \multirow{5}{*}{ No. 19} & Zea mays columns with stigmas & 20.0 & 1 \\
& Urtica dioica leaf & 20.0 & 1 \\
& Taraxacum officinale roots & 20.0 & 1 \\
& Vaccinium myrtillus leaf & 20.0 & 1 \\
& Rosa majalis fruits & 20.0 & 1 \\
\hline
\end{tabular}

\section{Phytochemical compounds and its mechanism of influence on the pathogenesis of diabetes mellitus}

Carbohydrates obtained from plants are very important active substances for the prevention and treatment of diabetes mellitus and diabetic angiopathies, because they have hypoglycemic, hypolipidemic, anticholesterolemic, antioxidant, anti-inflammatory and detoxifying activities. Polysaccharides stimulate the growth of beneficial bacteria in the colon, including Bifidobacteria and Lactobacilli, thereby modulating the composition of microflora. This creates an environment that protects against pathogens, toxins and free radicals resulting from lipid peroxidation. Powerful antioxidant properties of polysaccharides in number of studies in vivo and in vitro, whose mechanism of action is not understood exactly, have been observed. Plant carbohydrates have the ability to regulate the lipid metabolism by lowering of triglycerides and 
cholesterol, a disorder of which occurs in diabetes and leads to the development of cardiovascular diseases and microcirculatory complications - diabetic nephropathy, neuropathy and retinopathy, the formation of diabetic foot. The hypoglycemic activity of carbohydrates is realized by increasing of insulin secretion, inhibition of glucagon secretion, stimulation of $\beta$-cells proliferation and neogenesis ${ }^{15,16}$. In addition, they also show anti-inflammatory properties, which are manifested by reducing the parameters of inflammation such as edema, leukocyte migration and nociception ${ }^{17}$. All these carbohydrates properties make them an important group of substances for prevention and treatment of diabetes mellitus and their extremely dangerous complications.

During gas chromatography-mass spectrometry (GC-MS) analysis were identified and established content of a number of carbohydrates $\mathrm{i}$ free and bound form in the studied herbal mixtures, namely polyalcohols, mosaccharides and disaccharides ${ }^{18}$. The chromatographic study revealed a number of sugar alcohols, which are often used as sweeteners for diabetics because they have fewer calories and are poorly digested carbohydrates that are only partially absorbed from the small intestine and are not metabolized. Pinitol - a cyclic polyol, is known as an antidiabetic agent that has a hypoglycemic effect, reduces lipid peroxidation, protects liver, kidneys and pancreas. Myo-inositol, which present in the free and bound form in the herbal mixtures, together with D-chiro-inositol are two inositol stereoisomers, which are acting like insulin mediators. These polyalcohols are involved in increasing insulin sensitivity of body tissues, which reduces insulin resistance as one of the main pathogenetic mechanisms of development of diabetes mellitus type $2^{19,20}$.

${ }^{15}$ Ganesan K., Xu B. Anti-diabetic effects and mechanisms of dietary polysaccharides. Molecules. 2019. Vol. 24. 2556. DOI: 10.3390/molecules24142556.

${ }^{16}$ Synergistic hypoglycemic effects of pumpkin polysaccharides and puerarin on type II diabetes mellitus mice / X. Chen, L. Qian, B. Wang [et al.] // Molecules. 2019. Vol. 24(5). 955. DOI: 10.3390/molecules24050955.

${ }^{17}$ Neelakandan Y., Venkatesan A. Antinociceptive and anti-inflammatory effect of sulfated polysaccharide fractions from Sargassum wightii and Halophila ovalis in male Wistar rats. Indian Journal of Pharmacology. 2016. Vol. 48(5). P. 562-570. DOI: 10.4103/0253-7613.190754.

${ }^{18}$ Savych A., Marchyshyn S., Milian I. Determination of carbohydrates in the herbal antidiabetic mixtures by GC-MC. Acta Pharmaceutica. 2021. Vol. 71. Article in press. DOI: 10.2478/acph-2021-0026.

${ }^{19}$ Bates S.H., Jones R.B., Bailey C.J. Insulin-like effect of pinitol. British Journal of Pharmacology. 2000. Vol. 130(8). P.1944-1948. DOI: 10.1038/sj.bjp.0703523. 
Besides, it was detected high content of inulin in the investigated herbal mixtures by the products of its enzymatic hydrolysis after conversion into volatile derivatives as aldononitrile acetate using GC-MS. Inulin is an important substance of natural origin, which has hypoglycemic, hypolipidemic, anticholesterolemic and detoxifying activities and it indicate the advisability of the using of these phytomixtures as promising herbal medicines for the prevention and treatment of diabetes mellitus and its complications.

For phytotherapy, the important biologically active substances are polyphenols. They comprise a wide range of phytochemical compounds from following group: phenolic acids, flavonoids, tannins, stilbenes, coumarins, and lignans. Phenolic acids are usually classified into two major groups: benzoic acids, containing seven carbon atoms (C6-C1), and cinnamic acids, comprising nine carbon atoms (C6-C3). Among various biological activities, hydroxycinnamic acids are associated with the positive effect on diabetes and its complications, mainly due to the presence of hypoglycemic and antioxidant activities. Their antidiabetic effect implemented by different mechanism of actions, including stimulation of insulin secretion, improvement of pancreatic $\beta$-cell functionality, inhibition of gluconeogenesis, intensification of glucose uptake, delay of carbohydrate digestion and glucose absorption, inhibition of protein glycation and insulin fibrillation. The antioxidant activity of these compounds is due to the fact that cinnamic acid and its derivatives neutralize free radicals by cleavage of the hydrogen atom ${ }^{21}$.

The chemical structure of flavonoids is based on fifteen-carbon skeleton consisting of two benzene rings linked via a heterocyclic pyrane ring. The pharmacological activities of this biocompounds depend on their structural class, degree of hydroxylation, other substitutions and conjugations, and degree of polymerization. In particular, functional hydroxyl groups in flavonoids mediate their antioxidant effects by scavenging free radicals and/or by chelating metal ions ${ }^{22}$.

${ }^{20}$ Chhetri D.R. Myo-inositol and its derivatives: their emerging role in the treatment of human diseases. Frontiers in Pharmacology. 2019. Vol. 10. 1172. DOI: 10.3389/fphar. 2019.01172 .

${ }^{21}$ Dietary polyphenols and gene expression in molecular pathways associated with type 2 diabetes mellitus: a review / G.G. Kang, N. Francis, R. Hill et al. International Journal of Molecular Sciences. 2019. Vol. 21(1). P. 140. DOI: 10.3390/ijms 21010140.

${ }^{22}$ Panche A. N., Diwan A. D., Chandra S. R. Flavonoids: an overview. Journal of nutritional science. 2016. Vol. 5. e47. DOI: 10.1017/jns.2016.41. 
Antioxidant activity of flavonoids in the treatment and prevention of diabetes and its complications is important because they can include suppression of ROS formation either by inhibition of enzymes or by chelating trace elements involved in free radical generation; scavenging ROS; inhibition the enzymes involved in ROS generation microsomal monooxygenase, glutathione S-transferase, mitochondrial succinoxidase, nicotinamide adenine dinucleotide phosphate (NADH) oxidase, and so forth.

The results of qualitative detection of flavonoids and hydroxycinnamic acids and their quantitative content in the herbal mixtures showed the high content of these polyphenols ${ }^{23}$.

Rutin, as as the major component in the herbal mixtures, has numerous peripheral activities, such as antioxidant, anti-inflammatory, cardiovascular, neuroprotective, antidiabetic, and anticancer. Luteolin, a flavone, is reportedly important bioflavonoid, which exhibits a number of pharmacological effects, such as antioxidant, antihyperglycemic, antidiabetic, anti-inflammatory, hepatoprotective, antiallergic, antiosteoporotic, anticancer, antiplatelet and vasodilatory properties. Flavonols, such as quercetin and its glycosides (rutin, isoquercetin), that were detected during HPLC analysis have powerful antioxidant activities, which are manifested due to their chemical structure, which provides the cleavage of hydrogen atoms. In addition, flavonols increases the production of GSH and antioxidant enzymes - SOD and CAT, as well as inhibits xanthine oxidase, which is involved in the generation of $\operatorname{ROS}^{24}$.

The high content of chlorogenic acid in the studied mixtures is a positive thing, because it has a pronounced hypoglycemic activity, due to the fact that it increases the using of glucose by skeletal muscles, improves glucose tolerance, stimulates insulin secretion by pancreatic $\beta$ cells. In addition, chlorogenic acid has the ability to potentiate the action of insulin, similar to the therapeutic action of metformin - synthetic antidiabetic drug of the biguanide class. It is also important that chlorogenic acid has the ability to regulate lipid metabolism by a

${ }^{23}$ Савич А.О., Марчишин С.М., Кравчук Л.О. Дослідження якісного складу та кількісного вмісту флавоноїдів у зборах антидіабетичних № 3 і № 4 методом ВЕРХ. Актуальні питання фармацевтичної і медичної науки та практики. 2020. Т. 13, № 2(33). C. 219-224. DOI: 10.14739/2409-2932.2020.2.207118.

24 Rutin as a Potent Antioxidant: Implications for Neurodegenerative Disorders. Oxidative medicine and cellular longevity / A.B. Enogieru et al. 2018. P. 6241017. DOI: $10.1155 / 2018 / 6241017$ 
decrease in triglycerides, low-density lipoproteins and cholesterol, which is signify to prevent the development of cardiovascular diseases and microcirculatory complications - diabetic nephropathy, neuropathy and retinopathy, the formation of diabetic foot. Diabetes mellitus is often accompanied by the development of metabolic syndrome, which is characterized by obesity, and chlorogenic acid helps to lose the weight and to reduce the accumulation of visceral fat, activates fat metabolism in the liver, contributes to lowering the level of plasma leptin. In addition, chlorogenic acid has strong antioxidant properties, which is important for the prevention of diabetic angiopathies, the pathogenesis of which are activation of lipid peroxidation, inactivation of antioxidant protection system and development of oxidative stress. Antioxidant properties of chlorogenic acid are realized by cleavage of hydrogen atoms, which reduces the amount of free radicals, lipid peroxidation products and inhibits the development of oxidative stress. The development of inflammatory processes in patients with diabetes mellitus is an important problem that requires pharmacocorrection. It can solve this problem by using of chlorogenic acid which exhibits antiinflammatory properties, which are manifested by reducing of edema, effectively suppressing the pro-inflammatory cytokines, reducing of neutrophil infiltration ${ }^{25}$.

$p$-Coumaric acid, which contained in the herbal mixtures, has many biological activities, such as hypoglycemic, powerful antioxidant, antiinflammatory, hepato-renal protective effects and protects the pancreas from free radical damage. Thus, $p$-coumaric acid is a good agent for lowering blood glucose, decreasing oxidative stress, improving antioxidant status, diminishing inflammation ${ }^{26}$.

Ferulic acid is very impotent agent for prevention and treatment of diabetes mellitus, because it has hypoglycemic effect, which occurs by multiple mechanisms - inhibition of $\alpha$-glucosidase, stimulation of insulin secretion, increasing glucose utilization; antioxidant effect due to its ability to prevent protein glycation and membrane lipid peroxidation, by neutralizing the free radicals formed.

25 Adisakwattana S. Cinnamic acid and its derivatives: mechanisms for prevention and management of diabetes and its complications. Nutrients. 2017. Vol. 9(2). P. 163. DOI: $10.3390 /$ nu9020163.

${ }^{26}$ Hydroxycinnamic acid derivatives: a potential class of natural compounds for the management of lipid metabolism and obesity. Nutrition \& Metabolism / M.A. Alam et al. 2016. Vol. 13. P. 27. DOI: 10.1186/s12986-016-0080-3 
Sinapic acid has numerous peripheral activities, such as antioxidant, anti-inflammatory, hypoglycemic, cardioprotective, hepatoprotective and nephroprotective. Its hypoglycemic effect is implemented by reduction of insulin resistance and glucose concentration in plasma, increasing of GLUT4 gene expression in skeletal muscle and sensitivity of cells to insulin. In addition, it has the ability to regulate lipid metabolism by a decreasing of triglycerides and cholesterol ${ }^{24}$.

Cinnamic acid exhibits antidiabetic properties by different mechanism of actions, including stimulation of insulin secretion, improvement of pancreatic $\beta$-cell functionality, inhibition of gluconeogenesis, increased glucose uptake, improved glucose tolerance. In addition, it has antioxidant, hepatoprotective and anti-inflammatory activities ${ }^{27}$.

Fatty acids are very important active substances for the treatment and improving of the course of diabetes, because its prevent the oxidation of cell membrane lipids, contribute to the reduction of blood cholesterol, normalize lipid and protein metabolism, increase the liver's detoxification function, stimulate immune-protective function, increase the elasticity and reduce the permeability of the walls of blood vessels, improve microcirculation ${ }^{28}$. Particularly important for the human body is linoleic acid that is part of the omega- 6 fatty acids, and linolenic acid of omega-3 fatty acids, which was identified in the herbal mixtures by GC- $\mathrm{MS}^{29}$. These fatty acids have ability to normalize the function of cellular and subcellular membranes.

Macro- and microelements are important in the development and course of diabetes, as many of them are involved in the regulation of carbohydrate metabolism. In particular, $\mathrm{Zn}$ is part of the structure of insulin, increases the duration of its hypoglycemic action, and persistent hyperglycemia, in turn, leads to increased excretion of $\mathrm{Zn}$ from the body, worsens the course of diabetes and its complications. Zn deficiency also contributes to the development of oxidative stress and cell destruction. $\mathrm{Cr}$ increases the activity of insulin, it is the central atom in the molecule

${ }^{27}$ Antioxidant plants and diabetes mellitus. Journal of research in medical sciences : the official journal of Isfahan University of Medical Sciences / H. Nasri et al. 2015. Vol. 20 (5). P. 491-502. DOI: 10.4103/1735-1995.163977

${ }^{28}$ Omega-3, omega-6, and total dietary polyunsaturated fat for prevention and treatment of type 2 diabetes mellitus: Systematic review and meta-analysis of randomised controlled trials / T. J. Brown, J. Brainard, F. Song F. et al. BMJ. 2019. Vol. 366. 14697. DOI: 10.1136/bmj.14697.

${ }^{29}$ Savych A., Marchyshyn M., Basaraba R. Determination of fatty acid composition content in the herbal antidiabetic collections. Pharmacia. 2020. Vol. 67(3). P. 153-159. DOI: 10.3897 /pharmacia.67.e51812. 
of a hormone-like substance - glucose uptake factor (GLUT) - glucose tolerance factor, which functions in combination with insulin and transports glucose across cell membranes. Cr deficiency plays a role in the formation of diabetic neuropathy. There is evidence of a link between the development of diabetes and Se levels in the body. Mn deficiency can contribute to the development of type 2 diabetes. $\mathrm{Cu}, \mathrm{Fe}, \mathrm{Mg}$ are involved in the synthesis of proteins and enzymes necessary for normal metabolism ${ }^{30}$. Atomic absorption spectrophotometry showed that the studied herbal mixtures contain a sufficiently high number of macro- and microelements and this indicates their prospects for use to optimize the pharmacotherapy of diabetes and its complications ${ }^{31}$.

\section{CONCLUSIONS}

It was established for the first time, the relationship between the phytochemical composition and pharmacological properties of the herbal mixtures No. 3 (Urtica dioica leaf, Cichorium intybus roots, Rosa majalis fruits, Elymus repens rhizome, Taraxacum officinale roots) No. 4 (Arctium lappa roots, Elymus repens rhizome, Zea mays columns with stigmas, Helichrysum arenarium flowers, Rosa majalis fruits), No. 7 (Inula helenium rhizome with roots, Helichrysi arenarium flowers, Zea mays columns with stigmas, Origanum vulgari herb, Rosa majalis fruits, Taraxacum officinale roots), No. 13 (Cichorium intybus roots, Elymus repens rhizome, Helichrysum arenarium flowers, Rosa majalis fruits, Zea mays columns with stigmas), No. 19 (Urtica dioica leaf, Taraxacum officinale roots, Vaccinium myrtillus leaf, Rosa majalis fruits, Mentha piperita herb). It was substantiated the mechanism of action of biologically active substances contained in the studied herbal mixtures on various links of the pathogenesis of diabetes mellitus and its complications.

The obtained results allow us to predict the possible use of the investigated herbal mixtures for optimization of antidiabetic pharmacotherapy, with the advisability of their further pharmacological and phytochemical research.

30 Мерецький В., Шманько В. Сучасні погляди на роль мікроелементів у патогенезі цукрового діабету. Ліки Украӥни. 2009. № 3. С. 32-35.

31 Савич А.О., Марчишин С.М. Аналіз мінерального складу рослинних антидіабетичних зборів. Медична та клінічна хімія. 2020. Т. 22, № 2. С. 81-86. DOI: 10.11603/mcch.2410-681X.2020.v.i2.11364. 


\section{SUMMARY}

The herbal mixtures due to the wide range of biologically active substances can influence on various links of the mechanism of development of diabetes mellitus, pathogenesis of which involves the development of insulin resistance, relative insulin deficiency, which leads to the decrease of secretory activity of $\beta$-cells of the pancreatic gland, and its complications, pathogenesis of which is inactivation of antioxidant protection system, activation of lipid peroxidation and development of oxidative stress.

Thus, the aim of the research was to study the relationship between previously identified phytocomponents of the investigated herbal mixtures and their pharmacodynamics and effectiveness in the treatment and prevention of diabetes mellitus type 2 and its complications.

Previously detected carbohydrates, such as monosaccharides, disaccharides, polyalcohols and inulin, in the herbal mixtures show hypoglycemic, hypolipidemic, anticholesterolemic, antioxidant, antiinflammatory and detoxifying activities. The polyphenols present in the herbal mixtures, such as flavonoids and hydroxycinnamic acids, have the following properties: hypoglycemic, antioxidant, hypolipidemic, antiinflammatory, cardioprotective, neuroprotective, nephroprotective, anticancer, hepatoprotective, antiallergic, antiosteoporotic, antiplatelet and vasodilatory properties. Fatty acids, which was detected in the herbal mixtures, are very important active substances for the treatment and improving of the course of diabetes, because its prevent the oxidation of cell membrane lipids, contribute to the reduction of blood cholesterol, normalize lipid and protein metabolism, increase the liver's detoxification function, stimulate immune-protective function, increase the elasticity and reduce the permeability of the walls of blood vessels, improve microcirculation. In addition, a number of identified micro- and macroelements are involved in the regulation of carbohydrate metabolism by various mechanisms of action.

All biologically active substances found in previous studies in herbal mixtures have a positive effect on the course, treatment and prevention of diabetes mellitus type 2 and its complications, which was confirmed in previous pharmacological studies in vivo. 


\section{REFERENCES}

1. Sakamoto M. Type 2 diabetes and glycemic variability: various parameters in clinical practice. Journal of Clinical Medicine Research. 2018. Vol. 10 (10). P. 737-742. DOI: 10.14740/jocmr3556w.

2. International Diabetes Federation. IDF Diabetes Atlas., 9th edn. Brussels, Belgium, 2019. URL: http://www.diabetesatlas.org.

3. American Diabetes Association, Standards of medical care in diabetes. Diabetes care. 2020. Vol. 43. 1212 p.

4. Differentiation of diabetes by pathophysiology, natural history, and prognosis. Diabetes / J.S. Skyler et al. 2017. Vol. 66 (2). P. 241-255. DOI: $10.2337 / \mathrm{db} 16-0806$.

5. Phytotherapy in the management of diabetes: a review. Molecules / P. Governa et al. 2018. Vol. 23. P. 105. DOI: 10.3390/molecules 23010105.

6. Основні принципи використання лікарських рослин та їх зборів для лікування та профілактики цукрового діабету 2 типу (Огляд літератури). Фітотерапія часопис / А.О. Савич та ін. 2019. № 4. C. 43-46. DOI: 10.33617/2522-9680-2019-4-43.

7. Товстуха С.С. Золоті рецепти української народної медицини. Київ : Країна Мрій, 2010. 550 с.

8. Savych A., Marchyshyn S., Basaraba R. Screening study of hypoglycemic activity of the herbal mixtures (Message 1). Scientific Journal «ScienceRise: Pharmaceutical Science». 2020. Vol. 4 (26). P. 40-46. DOI: 10.15587/2519-4852.2020.210734

9. Savych A., Marchyshyn S., Doroshenko O. Screening of hypoglycemic activity of herbal mixtures (Message 2). Ukrainian biopharmaceutical journal. 2020. Vol. 3 (64). P. 22-29. DOI: 10.24959/ubphj.20.281

10. Savych A.O., Marchyshyn S.M., Milian I.I. Screening study of hypoglycemic activity of herbal mixtures (Presentation 3). Clinical Pharmacy. 2020. Vol. 24 (4). P. 38-46. DOI: 10.24959/cphj.20.1537.

11. World Health Organization.WHO Guidelines on Good Agricultural and Mixture Practices (GACP) for Medicinal Plants. Geneva, 2003. P. 72. URL: https://apps.who.int/iris/handle/10665/42783.

12. Antihyperglycemic, hypolipidemic and antioxidant properties of the herbal mixtures in dexamethasone-induced insulin resistant rats. Pharmacologyonline / A. Savych et al. 2020. Vol. 2. P. 73-82.

13. Savych A.O., Marchyshyn S.M. Influence of the herbal mixtures on the functional state of the liver in dexamethasone-induced insulin resistant rats. New trends and unresolved issues of preventive and clinical medicine : materials of the international scientific and practical conference. (Lublin, Republic of Poland, 23-24 of September, 2020). Lublin, 2020. P. 113-116. DOI: 10.30525/978-9934-588-81-5-2.27 
14. Savych A., Marchyshyn M. Effect of the herbal mixture on protein metabolism in dexamethasone-induced insulin resistant rats. International E-conference contemporary pharmacy: issues, challenges and expectations : materials of the conference. (Kaunas, Lithuania, 23 of October, 2020). Kaunas, 2020. P. 59.

15. Ganesan K., Xu B. Anti-diabetic effects and mechanisms of dietary polysaccharides. Molecules. 2019. Vol. 24. 2556. DOI: 10.3390/ molecules24142556.

16. Synergistic hypoglycemic effects of pumpkin polysaccharides and puerarin on type II diabetes mellitus mice. Molecules / X. Chen et al. 2019. Vol. 24 (5). 955. DOI: 10.3390/molecules 24050955

17. Neelakandan Y., Venkatesan A. Antinociceptive and anti-inflammatory effect of sulfated polysaccharide fractions from Sargassum wightii and Halophila ovalis in male Wistar rats. Indian Journal of Pharmacology. 2016. Vol. 48 (5). P. 562-570. DOI: 10.4103/0253-7613.190754.

18. Savych A., Marchyshyn S., Milian I. Determination of carbohydrates in the herbal antidiabetic mixtures by GC-MC. Acta Pharmaceutica. 2021. Vol. 71. Article in press. DOI: 10.2478/acph-2021-0026.

19. Bates S.H., Jones R.B., Bailey C.J. Insulin-like effect of pinitol. British Journal of Pharmacology. 2000. Vol. 130 (8). P. 1944-1948. DOI: $10.1038 /$ sj.bjp.0703523.

20. Chhetri D.R. Myo-inositol and its derivatives: their emerging role in the treatment of human diseases. Frontiers in Pharmacology. 2019. Vol. 10. 1172. DOI: 10.3389/fphar.2019.01172.

21. Dietary polyphenols and gene expression in molecular pathways associated with type 2 diabetes mellitus: a review. International Journal of Molecular Sciences / G.G. Kang et al. 2019. Vol. 21 (1). P. 140. DOI: 10.3390/ijms21010140.

22. Panche A.N., Diwan A.D., Chandra S.R. Flavonoids: an overview. Journal of nutritional science. 2016. Vol. 5. e47. DOI: 10.1017/jns.2016.41.

23. Савич А.О., Марчишин С.М., Кравчук Л.О. Дослідження якісного складу та кількісного вмісту флавоноїдів у зборах антидіабетичних № 3 і № 4 методом ВЕРХ. Актуальні питання фармацевтичної $і$ медичної науки та практики. 2020. Т. 13. № 2 (33). C. 219-224. DOI: 10.14739/2409-2932.2020.2.207118.

24. Rutin as a Potent Antioxidant: Implications for Neurodegenerative Disorders. Oxidative medicine and cellular longevity / A.B. Enogieru et al. 2018. P. 6241017. DOI: 10.1155/2018/6241017.

25. Adisakwattana S. Cinnamic acid and its derivatives: mechanisms for prevention and management of diabetes and its complications. Nutrients. 2017. Vol. 9 (2). P. 163. DOI: 10.3390/nu9020163. 
26. Hydroxycinnamic acid derivatives: a potential class of natural compounds for the management of lipid metabolism and obesity. Nutrition \& Metabolism / M.A. Alam et al. 2016. Vol. 13. P. 27. DOI: 10.1186/s12986-016-0080-3.

27. Antioxidant plants and diabetes mellitus. Journal of research in medical sciences : the official journal of Isfahan University of Medical Sciences / H. Nasri et al. 2015. Vol. 20 (5). P. 491-502. DOI: 10.4103/ 1735-1995.163977.

28. Omega-3, omega-6, and total dietary polyunsaturated fat for prevention and treatment of type 2 diabetes mellitus: Systematic review and meta-analysis of randomised controlled trials. $B M J$ / T.J. Brown et al. 2019. Vol. 366. 14697. DOI: 10.1136/bmj.14697.

29. Savych A., Marchyshyn M., Basaraba R. Determination of fatty acid composition content in the herbal antidiabetic collections. Pharmacia. 2020. Vol. 67 (3). P. 153-159. DOI: 10.3897/pharmacia.67.e51812.

30. Мерецький В., Шманько В. Сучасні погляди на роль мікроелементів у патогенезі цукрового діабету. Ліки Украйни. 2009. № 3. C. 32-35.

31. Савич А.О., Марчишин С.М. Аналіз мінерального складу рослинних антидіабетичних зборів. Медична та клінічна хімія. 2020. T. 22. № 2. C. 81-86. DOI: 10.11603/mcch.2410-681X.2020.v.i2.11364.

\section{Information about the authors:} Savych A. O.,

Candidate of Pharmacy (Ph.D.), Assistant Professor at the Department of Pharnacognosy with Medical Botany Ivan Horbachevsky Ternopil National Medical University 1, Voli square, Ternopil, 46001, Ukraine

Marchyshyn S. M., Doctor of Pharmacy (Dr.habil.), Professor, Head of the Department of Pharnacognosy with Medical Botany Ivan Horbachevsky Ternopil National Medical University 1, Voli square, Ternopil, 46001, Ukraine 